Ismar Velić, Ph.D. student,

University of Rijeka, Faculty of Economics, Rijeka, Croatia

velicismar@gmail.com

\title{
COPENHAGEN CRITERIA AND WESTERN BALKAN CANDIDATE COUNTRIESFOR MEMBERSHIP IN EUROPEAN UNION: CASE OF BOSNIA AND HERZEGOVINA
}

Received: October 20, 2018

Accepted: December 20, 2018

\section{Abstract}

The European Union (EU) has shown considerable interest in receiving the Western Balkan countries into the EU, as did the mentioned countries show considerable interest to join the EU. Although this is a historically very turbulent region, the EU has clearly, unambiguously and unanimously expressed the political attitude towards the Western Balkans:"The Future of the Balkans is in the European Union". In addition to goodwill, the EU is also ready to assist in this process but also each country must do its part of the job in the accession process. The very process of EU accession means defining and meeting necessary criteria for potential new EU members, as well as the process of accession negotiations for the full membership of the new member states. The main objective of this article is to indicate which expansion criteria or Copenhagen criteria will be the most critical to achieve for Bosnia and Herzegovina(B\&H), as one of the Western Balkan countries, in the process of access into the EU. In the process of meeting Copenhagen criteria, unlike other Western Balkan countries, B\&H shows the least success. In our research, Bosnia and Herzegovina has a problem primarily by satisfying political Copenhagen criteria and then meeting economic and legal criteria. The lack of meeting Political Copenhagen criteria is found primarily in the absence of political consensus in $B \& H$, which stems from the special features of the Government in Bosnia and Herzegovina (two entities and Bosnia's three main ethnic populations). With the lack of political unity in $B \& H$, it is not possible to establish stable institutions that ensure democracy, the rule of law, respect for human rights and the right to protect minorities (Sejdic and Finci case, corruption, non-transparent elections, nondependent media and labour unions) Fulfilling the Copenhagen Economic Criteria - a functioning market economy is also dependent on political influence (which is also fractured). The economy of $B \& H$ is structurally unregulated and is based on the processing of basic raw materials without the high-tech industry in order to deal with the competition of the European Single Market. During the research, the used scientific methods (analysis and syntheses, descriptions and classifications, historical and 
comparative, induction and deduction, and quantitative analysis) showed that it would be most difficult to achieve the political and economic Copenhagen criteria for the above reasons.

Keywords: European integration, Western Balkan countries, Bosnia and Herzegovina, Copenhagen criteria

JEL: 052

\section{INTRODUCTION}

Why should the countries of the Western Balkan consider and work intensively on their European integration? The answer to this question is found in the history of Europe, which unfortunately has often been marked by conflicts between major European tribes and then nations and states. From the ancient times to the present, the period of greatest prosperity and peace experienced by Europe is the period of European integration, if the 1990s Balkan conflicts that tore apart the former Yugoslavia are excluded. Although the idea of European unity can be tracked prior to the 20th century, the European integration process really began after the Second World War. European integration marked an end to the conflicts that had been tearing the European continent initiating reconciliation between France and Germany after centuries of tensions. The European Union (EU), however, is not a product of force or domination, but cooperation that was built over a period of decades and a free will of governments and peoples who had decided to unite to guarantee peace and justice, and abandon nationalist aspirations (Kandžija, Cvečić, 2010, 78). European integration can serve as a good example in context of alleviating existing tensions among the Balkan countries and peoples in Bosnia and Herzegovina $(\mathrm{B} \& \mathrm{H})$, which is the focus of this paper. The process of reconciliation in Europe can serve as a bright example in context of joining efforts to ensure longlasting peace and the EU shows how civilisation values can be promoted such as democracy development, rule of law, effective institutions and efficient economies. These are the values that a modern country should aspire to, and on which the EU is insisting, as well as on resolving international problems in terms of good neighbourly relations (regional cooperation). It is also necessary to consider globalization processes that involve countries grouped into political and economic blocs aimed at securing competitive advantage vis-a-vis rivals in the global market. It is therefore quite natural for the countries of the Western Balkans to integrate into a group with neighbouring countries on the continent to which they belong.

Considering the turbulent history of the Balkans and current situation in the region characterised by rather slow socio-economic development, it can be assumed that European integration, by its principles and resources, represents for the Balkan countries the best way to achieve democracy, rule of law, minority rights, civil 
rights, economic development, good neighbourly relations, peace and stability in a colourful region such as the Western Balkans. This is the answer to the question posed in the introduction. It seems that the Balkan countries (primarily EU members: Slovenia and Croatia, and others on that path) have recognized the logic and importance of European integration as well as B\&H which is the focus of this paper. This is confirmed by the official standpoint of B\&H's Ministry of Foreign Affairs that B\&H's strategic priority is EU membership (Ministarstvo vanjskih poslova $\mathrm{BiH}, 2015)$. According to the Ministry, $\mathrm{B} \& \mathrm{H}$ 's aspiration to gain full membership in the EU is based on a consensus between political parties, which in practice is quite questionable as will be discussed in the next chapters. In January and February 2015, the Presidency and the Parliamentary Assembly of B\&H adopted a Joint Declaration of Commitment to Reforms in the EU accession process of $B \& H$ (Ministarstvo vanjskih poslova $\mathrm{BiH}, 2015$ ). The Western Balkan countries and its peoples are pursuing full EU membership aimed at achieving the goals of development and stability (Kandžija, Tomljanović, Kandžija, 2015, 142). Integration of Bosnia and Herzegovina is even more significant as it is viewed as an adequate solution to achieve and maintain its existence and stability, as will be provided in this paper. Moreover, it seems that the set of conditions on which the EU insists is an excellent control mechanism of action of disunited political structure in this country. In order to provide aid to the Western Balkan countries in solving their economic and political problems, the EU has created special financial instruments (Kandžija, Tomljanović, Kandžija, 2015, 142). EU funds are allocated to specific projects where each country is responsible for its own progress (Kandžija, Tomljanović, Kandžija, 2015, 142). The aim of this paper is to identify the key issues facing $\mathrm{B} \& \mathrm{H}$ and challenges it will face to meet the requirements of EU accession aimed at being eligible to receive EU funding. Considering the diversity of nations in Bosnia and Herzegovina, it is a country that most recalls the European Union, which is characterised by adversity of nations members of the EU. The EU has succeeded in solving the problems of different nations and states and setting the highest civilization standards and has long supported its partners in the Western Balkans, including $\mathrm{B} \& \mathrm{H}$, on their respective integration paths. The paper will focus on important aspects of the European integration process such as the Copenhagen criteria for the accession of Bosnia and Herzegovina to the EU.

\subsection{Research methodology}

Various methods have been used in conducting this scientific research. One of the primary methods that were used was the historical method for determination of chronology and development of complex relations in $\mathrm{B} \& \mathrm{H}$, which are the critical obstacles to B\&H's integration. Other methods involved description and classification of the roles and criteria of European integration that may be applied to $\mathrm{B} \& \mathrm{H}$. Furthermore, the method of analysis and synthesis of the influence of socio-political relations on the socio-economic structure and development of the country and its integration towards the EU was used, as well as the analysis and 
synthesis of the effects of European integration and the importance of its resources for $\mathrm{B} \& \mathrm{H}$. The induction and deduction method were used in creating assumptions and making conclusions based on the results of the research. The comparative method was used to compare $\mathrm{B} \& \mathrm{H}$ with other countries in the region and the selected EU members, based on available and relevant statistical data.

\section{LITERATURE REVIEW}

From the Dayton Agreement reached in 1995 to today, the Constitution of Bosnia and Herzegovina, which is an annex to the General Framework Agreement for Peace in Bosnia and Herzegovina, forms the basis of its Constitutional Law. According to Karan $(2014,161)$, the Constitution of B\&H does not explicitly define the form of state organization, which complicates determination of constitutional and factual relationships between the entities and common institutions of the country. Kuzmanović $(2004,157)$ believes that $\mathrm{B} \& \mathrm{H}$, which comprises of the two entities, can be a federation, confederation, confederal-federal alliance, asymmetric confederation or union, depending on how jurisdiction is divided between the state and the entities. B\&H does not have a clearly defined organization - a form of state organization (federal or confederal), which means that its rule of law and political system is not satisfactory, what makes an exceptional problem with the functioning of the country. According to Aybet and Bieber (2011, 1934), the establishment of the Office of the High Representative and the fact that the Constitution of $\mathrm{B} \& \mathrm{H}$ was created by international civil and military organizations, with the power to implement their decisions over local elites, gives $\mathrm{B} \& \mathrm{H}$ an apparent form of protectorate, making performance of the functions of interest articulation difficult. The Dayton Constitution defines B\&H's constitutional government and political system. B\&H is composed of the official authorities at the state level and the two entities. The Constitutional Law implies equality of the two entities and three constituent peoples, with the supremacy of the Constitution of $\mathrm{B} \& \mathrm{H}$. Such a constitution seems to be discriminatory against national minorities and in conflict with Copenhagen's political criteria. According to Pejanovic $(2017,4)$, the Constitution of B\&H gives primacy to the ethnic identities when forming official authorities where each entity gives primacy to the ethnic groups of which it consists in expressing their needs and demands to the government. Since the House of Representatives uses a majority vote decision rule with veto power and representatives are elected on an ethnic basis, it is difficult to achieve an absolute majority in the Parliament and the Government. According to Pejanović, such a political constellation is developed on partnerships and coalitions of different ethnic parties with completely opposite views, where reaching consensus is hard, making $\mathrm{B} \& \mathrm{H}$ seem a dysfunctional state in decision-making, legislation adoption and forming institutions. According to Nakić $(2013,39), \mathrm{B} \& \mathrm{H}$ shows the least progress in the European integration process of all candidate countries and potential candidates, because public opinion lacks of political will. Topčagić $(2016,2)$ also believes that the latest application for EU membership 
reflected a declarative readiness of political elites in $\mathrm{B} \& \mathrm{H}$. In support of such conclusion is the fact that $\mathrm{B} \& \mathrm{H}$ has not yet fulfilled the requirements for the $\mathrm{EU}$ accession. According to Kukić and Šavija (2017), submitting application for EU membership without having fulfilled the requirements for the EU accession may be considered lacking seriousness. The key issues referred to by the European Commission are the establishment of a functional coordination mechanism (Maletić, Kandžija, 2018, 242) and implementation of the Sejdić-Finci judgment of the European Court of Human Rights, in which the Court found a violation of Article 14 in relation to Article 3 of Protocol 1 of the European Convention on Human Rights and Fundamental Freedoms where the candidates were unable to run for elections in the House of Peoples of Bosnia and Herzegovina, and a violation of Article 1 of Protocol 12, where the candidates were unable to run for elections in the B\&H's Presidency (Kulenović, Hadžialić-Bubalo, Korajlić, 2011, 2). Although $B \& H$ has established an institution, which should function as a body that coordinates negotiations with the EU, the European Commission Report (Bosnia and Herzegovina 2018 Report) of April 2018 highlights that the National Program for the Adoption of the Acquis (European Commission, 2018, 5) has still not been implemented. The Sejdić-Finci judgement is a motive for analysing several aspects of the constitutional system of $\mathrm{B} \& \mathrm{H}$, in which non-constituent peoples in $\mathrm{B} \& \mathrm{H}$ are limited or excluded from political decision-making procedures byethnocratic elements, thus undermining the generally accepted elements of statehood (Kulenović, Hadžialić-Bubalo, Korajlić, 2011, 3). According to Kulenović, Hadžialić-Bubalo and Korajlić $(2011,3)$, the European Court of Human Rights has not set the time limit for the enforcement of the judgment, but the latest European Commission's report states that it is necessary to implement the judgement like in the cases of Pilav, Zornić and Šalaku, as well as the Constitutional Court's Decision to guarantee fundamental democratic rights of the citizens of Mostar in local elections, although the EU Accession and Stabilization Agreement has been signed. According to Rudolf (2011, 225) and Krešić (2014, 86), the Sejdić-Finci judgement opened Pandora's box and launched a Croatian issue. Two representatives of the Presidency of the Federation of Bosnia and Herzegovina are elected, and voters in FB\&H are not divided based on ethnic identity. All citizens can vote for representatives regardless of their ethnic identity. In three cases, a Croatian representative was elected by Bosniaks due to their number in this entity. Political problems facing B\&H are obstacles to B\&H's integration process. According to Pejanović $(2017,7)$, any slowdown in the integration process leads to destabilization of Bosnia and Herzegovina's society and economy as well as its integrity. According to Maletić and Kandžija (2018, 264), European integration is the key to the existence of its constituent peoples, equality of the Croatian people and further development and stability of B\&H. Hence, the following hypothesis is proposed in the research:

H1: Copenhagen political criteria will be viewed as the most critical obstacles to fulfilment of the requirements for B\&H's European integration. The lack of 
progress towards B\&H's European integration is a threat to its integrity and stability, and its transformation into a modern and prosperous state based on democracy, rule of law, minority rights, transparent institutions and economy.

In addition to many political issues that tend to slow the process of fulfilment of the Copenhagen political criteria, there are also economic ones, but they can only be resolved after the critical political issues are resolved. Pejanović $(2014,25)$ argues that the Constitution of $\mathrm{B} \& \mathrm{H}$ is irrational and expensive, as the Government, entities and cantons have a huge administration that requires $6 \%$ of total funds. Negative reactions from the EU and international community and the proposal for suspension of the Interim Agreement on trade and trade-related matters and IPE funding (Krešić, 2014, 87) for non-implementation of the SejdićFinci judgement; reveal a serious and very negative impact of political disunity on B\&H's economy. According to Palánkai (1997, 53), the implementation of Copenhagen economic criteria requires a functioning market economy and the capacity to cope with competition and market forces. According to Hodžić (2012, 84), Kandžija, Pucar and Tolić (2016, 90), and most importantly according to the latest European Commission Report (European Commission, 2018, 30) B\&H is very far from that. The European Commission highlights the following B\&H's weaknesses: ineffective rule of law, poor business environment, fragmented and inefficient public administration, large labour market imbalances associated with poor education systems, poor institutional capacities and inadequate support for improving the investment environment (European Commission, 2018, 30). Kandžija and Maletić $(2018$, 30) argue that B\&H has not yet established the necessary structure for independently managing IPA funding. Fischer $(2006,447)$ and Tomaš $(2013,106)$ argue that partly responsible for current situation in $\mathrm{B} \& \mathrm{H}$ are international organizations that had participated in the creation of the state of $\mathrm{B} \& \mathrm{H}$ and its Constitution because it does not offer an adequate model for transition of economy. However, the co-responsibility of the international community does not diminish the responsibility of local political elites. According to data obtained from the Labour and Employment Agency of B\&H(Agencija za rad i zapošljavanje Bosne i Hercegovine, 2018), Federal Institute for Pension and Disability Insurance (FZ MIO - Federalnog zavoda za mirovinsko i invalidsko osiguranje, 2018) and Fund for Pension and Disability Insurance of Republic of Srpska (Fond PIO RS Fonda za penzijsko i invalidsko osiguranje Republike Srpske, 2018), there are extraordinary labour market imbalances and the number of retired workers is approaching the number of employed workers. The number of unemployed and retired workers in $\mathrm{B} \& \mathrm{H}$ has exceeded the number of employed workers. When analysing the competitiveness of B\&H's economy and its investment potential, the World Economic Forum (WEF) (2017-2018 and 2018) reveals a rather unfavourable image with slow advances in competitiveness growth. Kandžija, Pucar and Tolic $(2016$, 90) warn of the unsustainability of its economy whose export activity is based on the export of raw materials and semi-products. Hence, the following hypothesis is proposed in the research: 
H2: Political frictions in B\&H, which tend to slow down fulfilment of the political criteria set by the EU have a strong negative effect on B\&H's economy and implementation of urgent reform priorities.

The aim of the paper is to explore cause and effect relationships between indicators and prove the hypotheses after having established a positive approach of the EU towards all Western Balkan countries and a brief theoretical review of the accession criteria.

\section{EU'S ENLARGEMENT POLICY TOWARDS THE ACCESSION OF THE WESTERN BALKANS}

This chapter explores the EU's enlargement policy towards accession of the Western Balkan countries, particularly Bosnia and Herzegovina, and key accession criteria that concern those countries. The doors of the EU are open to further accessions of the countries of the Western Balkans and EU is willing to support its partners in the Western Balkans on their respective integration paths as announced in the introduction and as will be explained in more detail in this chapter. The following chapter will discuss the accession criteria that concern candidate and potential candidate countries.

\subsection{Positive attitudes towards accession of the countries of the Western Balkans}

EU has long supported the countries of the Central and Eastern Europe, including the Western Balkans, on their respective integration paths. Since the very beginning of European integration, positive attitudes towards EU enlargement can be found in the idea of Pan-European identity and unification of the European continent. The goal of EU is to unite European countries and peoples in particular with regard to human rights, democracy and peace (political goals) (Kandžija, Cvečić, 2010, 84). Article 49 of the EU Treaty defines that any European country that respects the principles set out in Article 2 of the EU Treaty (human dignity, freedom and equality, democracy and rule of law, human rights and fundamental freedoms, and societies founded on pluralism, non-discrimination, tolerance, justice, solidarity and gender equality), and countries willing to promote them can become members of the European Union (Kandžija, Cvečić, 2010, 208). The EU has shown its initiative and willingness to accept these countries by providing aid and giving loans to the former communist countries. In the period between 1991 and 1996 the EU concluded agreements with the countries of Central and Eastern Europe as well as three Baltic republics and Slovenia and promised to continue with further EU integration and providing aid (Kandžija, Cvečić, 2010, 211). European Union Association Agreements are based on the principles of human rights, democracy, rule of law and market economy, and their main objective was to prepare associated countries for membership in the EU primarily through establishment of a free trade zone for industrial products, as well as customs union 
within a period of ten years (Kandžija, Cvečić, 2010, 211), which is an important step in economic integration. The European Council met in Thessaloniki on $20-$ 21 June 2003. EU leaders confirmed to Balkan leaders that EU was ready to receive Balkan countries on the principles of democratic stability, rule of law and economic development (Europska unija, 2018). The Thessaloniki Summit organised under the Greek Presidency of the EU Council has strengthened the stabilization and association process with the aim of institutionalizing relationships between the EU and the Western Balkans, which is the goal of both the EU and the countries of the Western Balkans. However, it was clearly stated that the Western Balkan countries will become the institutional part of the EU only when they meet the accession criteria (Nakić, 2013, 37). At the meeting held in Salzburg in 2006, the EU confirmed that the future of the Western Balkans laid in the European Union, but also pointed out to the absorption capacity particularly regarding Turkey and Ukraine (as very complex cases) and highlighted individual achievements of candidate countries on their respective integration paths (Kandžija, Cvečić, 2010, 2017). It can be concluded that the EU has a positive attitude towards accession of the Western Balkan countries and EU enlargement but insists that candidates should fulfil their obligations regarding membership.

\subsection{EU accession criteria}

Apart from socio-political issues, European Union Association Agreements also involve economic ones, primarily in terms of free movement of capital investments and freedom of establishment to enable the countries of Central and Eastern Europe to get ready for competing on the EU market. It is therefore important to note the aspects of the EU Association Agreements:

- Political aspects - permanent consultation on issues of mutual interest,

- Trade aspects- creation of a free trade zone,

- Harmonization of legislation, particularly in the areas of competition and intellectual property rights,

- Economic, cultural and financial cooperation (Kandžija, Cvečić, 2010, 212).

At their Copenhagen Summit in June 1993, the EU leaders went one step further recognising that the countries of Central and Eastern Europe could join and become its full members. On 21 and 22 June 1993, the European Council defined the accession criteria or Copenhagen criteria which the candidate countries should meet for accession to the EU. The Copenhagen criteria are as follows:

- Political criterion - stable institutions that guarantee democracy, rule of law and minority rights,

- Economic criterion - a functioning market economy, capable of competing on the EU market,

- Legal criterion - undertaking obligations arising from membership involving alignment with the goals of political, economic and monetary 
union or adoption of the EU's acquits as the body of common rights and obligations that are binding on all EU countries, as EU Members (EURLex, 2018).

The Copenhagen accession strategy was reinforced at the Madrid Summit in 1995 by adding an administrative criterion, which implies the adjustment of administrative structures to create the conditions for the gradual, harmonious integration (EUR-Lex, 2018).

Each candidate country starts its accession process by submitting an official membership application after having fulfilled the pre-established accession criteria (Kandžija, Cvečić, 2010, 219). Considering that B\&H has difficulties in meeting almost all the criteria, it still has the status of a potential candidate. In the opinion of the author, meeting the economic criterion will be the most critical in the long run, as changes in the economy require the greatest effort by all the actors in society in dynamic global market. In order to be able to deal with its economic problems, B\&H authorities need to show more political maturity to achieve the necessary political consensus to reach other European countries in all categories and become eligible for EU funds to be used for implementing reforms.

\section{B\&HMOVING STEP BY STEP TOWARDS EU MEMBERSHIP}

B\&H's issues do not only arise from the diversity of its nations, cultures and religions, which, since conflicts in 1990s, affect its functionality setup. B\&H is a specific geopolitical region where three different civilization groups coexist, having three different versions of history or three different views on the history of $\mathrm{B} \& \mathrm{H}$, and where historians have failed to agree and lead to scientific consensus on essential issues (Šarčević, 1997, 123). Each group has its own idealized version of history neglecting the interests of other two groups, so historians fail to agree on a common point of view on historical foundations of $\mathrm{B} \& \mathrm{H}$, which also carries certain implications on the political interest articulation. Therefore, in addition to the historical aspect, it is necessary to explore some of the basic problems that hinder this country on its path to the EU integration.

\subsection{Specific issues and problems encountered in relation to the Constitution of $\mathbf{B} \& H$}

A specific concern encountered in relation with Bosnia and Herzegovina is related to its Constitution, which is the highest law of a country. B\&H is the only country whose constitution has not been written in the language spoken in that country. However, this is not a specific issue that is interesting for this work. A specific concern encountered in relation to the Constitutional Law of B\&H lies in the fact that the Constitution of B\&H was made as an annex to the Dayton Agreement, by which the international community sought to establish a lasting cease-fire as a step 
towards a peace process (Karan, 2014, 157). Excluding war aspects, the most important civilian aspect of the Dayton Agreement refers to the Constitution of Bosnia and Herzegovina and return of refugees and displaced persons (Pejanović, $2017,4)$, also one of the prerequisites for EU accession. Issues deriving from the Constitution of $\mathrm{B} \& \mathrm{H}$ are critical political and economic issues covered by the Copenhagen criteria (1993) and administrative ones defined in Madrid (1995).

According to the Dayton Constitution, B\&H is composed of the official authorities on the state level and the two entities: Federation of Bosnia and Herzegovina, which comprises of $51 \%$ of the land area and Republic of Srpska, which covers $49 \%$ of the land area. The Constitutional Law of Bosnia and Herzegovina implies equality between the two entities and three constituent peoples, with the supremacy of the Constitution of B\&H, which forms the basis of Constitutional Law. In addition to the two entities, the city of Brčko was granted the status of a district (Brčko District) by the international arbitration in 1999 and is united with the statelevel official authorities (Pejanović, 2017, 4). Like other agreements for peace, the Dayton Agreement imposes the ethnic principle in shaping institutions of the political system, where each entity gives priority to the ethnic group it comprises of in the interest articulation (Republic of Srpska - Serbs; Federation of Bosnia and Herzegovina - Bosniaks and Croats) (Pejanović, 2017, 4). The electoral system for the Parliamentary Assembly of B\&H is based on the ethnic principle. Electoral constituencies are set up within the entities (Republic of Srpska elects 14 representatives, while Federation of Bosnia and Herzegovina elects 28 representatives) (Pejanović, 2014, 25). B\&H is also specific in terms of delimitation of jurisdiction between the entities and state-level authorities (Kuzmanović, 2002, 305). The House of Representatives uses a majority decision vote rule with a veto power (Pejanović, 2014, 25). For this very reason, often no political consensus could be achieved and many proposed laws were not adopted.

Pursuant to the Dayton Constitution, each entity has been granted a broad legal power while the official authorities of $\mathrm{B} \& \mathrm{H}$ on the state level have a restricted power (Pejanović, 2017, 4). Such a political-constitutional structure makes B\&H not-functional, which results from monopolization and domination of ethnic parties in social development management (Pejanović, 2017, 4), but also dispersal of power to the state-level authorities, entities and ultimately to a range of regional units or cantons. Practice has shown that B\&H's ethnic parties do not have the power to achieve consensus on major issues of the country development. The state or the entities, therefore, cannot achieve a stable majority in the Parliament or Government (Pejanović, 2017, 6). For this reason, the country and its society fell into a crisis. Moreover, relationships between local political elites and international institutions become problematic. The problem stems from the diametrically opposed views of local political elites on the state and entity involvement, which makes the official state-level authorities too weak when engaged by international institutions (Aybet, Bieber, 2011, 1937). Instead of negotiating with a single 
official authority on the state level, international organizations must conduct relations with entity authorities. The European Commission had requested from $\mathrm{B} \& \mathrm{H}$ to establish an effective coordination mechanism as one of the conditions for starting negotiations. B\&H launched a coordination mechanism in June 2017, but the European Commission Report states that the EU's acquis has yet to be adopted (European Commission, 2018, 5). The EU's acquis forms a basis of the integration process.

The Constitution of B\&H does not explicitly define the form of state, which would simplify the determination of constitutional and factual relationships between entities and official state-level authorities of B\&H (Karan, 2014, 161). B\&H's constitutional structure looks very odd as it comprises of dominant elements of the federation together with some elements that are atypical for such a modern form of state organization (Karan, 2014, 161). Such a constitutional structure has very significant and far-reaching consequences for the state, legislation, freedom and civil rights and all social and statehood flows in B\&H (Karan, 2014). Considering that the Constitution of $\mathrm{B} \& \mathrm{H}$ was the result of political will and imagined participation of B\&H's citizens, it was not based on a form of popular consent (democratic legitimacy) (Karan, 2014, 157). As such, it is a product of will of the international community and a result of the compromise of political representatives of all three peoples (Karan, 2014). Bearing in mind that the Constitution is the highest law of a country, it should have been adopted according to the highest legislation standards with the widest democratic support of the people of $\mathrm{B} \& \mathrm{H}$ (Karan, 2014, 157). According to the Constitution, B\&H does not have a clearly defined organizational form - a form of state organization (federal or confederal), which means that its rule of law and political system is not satisfactory. There are different qualifications of the form of state organization of $\mathrm{B} \& \mathrm{H}$. Some argue that $\mathrm{B} \& \mathrm{H}$, which comprises of the two entities, can be a federation, a confederation, $a$ confederal-federal alliance, an asymmetric federation-confederation or a union depending on the division of jurisdiction between the state-level authorities and the two entities (Kuzmanović, 2004, 397). Furthermore, involvement of representatives of the international community or the High Representative gives B\&H an apparent form of protectorate. $\mathrm{B} \& \mathrm{H}$ as an international protectorate is a result of the fact that the Constitution of $\mathrm{B} \& \mathrm{H}$ was created by international civil and military organizations with the power to implement their decisions over local elites (Aybet, Bieber, 2011, 1934). Some, therefore, also argue that the problems encountered in relation to the Constitution and undefined form of state tends to slow down normal functioning of $\mathrm{B} \& \mathrm{H}$ as a state (Karan 2014, 164). Current form of state, with many elements of ethnic federalism, atypical and hybrid, is neither a guarantee nor a condition for proper performance of the state functions (Pobrić, 2000, 324). According to Pobrić $(2000,324)$, to become a regular state, Bosnia and Herzegovina must have a different constitution. This implies that defining B\&H as a form of state is a problem that carries widespread implications in terms of practical political life. Addressing this problem has a broader meaning than just 
political and legal because it reflects organization, structure and general functional setup of the state and society, its perspectives, economic development, cultural progress, peace and stability, and is an essential issue (Karan, 2014, 164). In building a functioning (federal) state, it is important to resolve several key issues such as division of jurisdiction between the state-level authorities and the entities, relationships and level of cooperation between the state-level authorities and entity authorities and the issue of equality of entities.

\subsection{Implications of constitutional issues on European Integration}

The European Commission adopted the Enlargement Package (2010/2012), which provides guidelines for the continuation of the enlargement process based on annual progress achieved by candidates and potential candidates of the Western Balkans on their respective integration paths to the EU(Nakić, 2013, 37). Western Balkans progress reports can be considered as optimistic about the continuation of the EU enlargement process and the advances made on the road to EU integration which requires a lot of efforts. However, $\mathrm{B} \& \mathrm{H}$ shows the least prospects and progress. According to Nakić, public opinion in B\&H lacks of adequate political support (Nakić, 2013, 39). It seems that very little changed five years after 2013, apart from slight moves towards the EU membership. Building a functioning and sustainable state is the key to start making a progress (Nakić, 2013, 39). The latest attempt to move forward was made on February 15, 2016, when Dragan Čović, Chairman of the Presidency of B\&H submitted B\&H's application for EU membership (Europa, 2016). However, the seriousness of the application is at least questionable because the application was filed even though $\mathrm{B} \& \mathrm{H}$ has not yet fulfilled the three conditions set out in the European Commission's Progress Report for 2015. Moreover, the European Commissioner for European Neighbourhood Policy and Enlargement warned that at least two of the three conditions should be met: implementation of an effective coordination mechanism and adaptation of the Stabilization and Association Agreement (SAA), upon entry of Croatia into the EU (Kukić, Šavija, 2017, 60). This reveals the problems encountered in relation to the Constitution of $\mathrm{B} \& \mathrm{H}$, as discussed in the previous chapter, which involves obligations deriving from the European Court of Human Rights Decision in the Sejdić and Finci v. B\&H case. The Court ruled that there had been a violation of Article 14 in relation to Article 3 of Protocol 1 of the European Convention on Human Rights and Fundamental Freedoms, where the candidates were unable to run for elections in the House of Peoples of Bosnia and Herzegovina and a violation of Article 1 of Protocol 12, where the candidates were unable to run for elections in the B\&H's Presidency (Kulenović, Hadžialić-Bubalo, Korajlić, 2011, 2). The judgement reveals that members of non-constituent peoples are unable to run for elections in the Presidency of $\mathrm{B} \& \mathrm{H}$ and the House of Peoples of the Parliamentary Assembly of B\&H (Kukić, Šavija, 2017, 60). This also indicates that the Constitution of $\mathrm{B} \& \mathrm{H}$ does not meet the main political criteria established in Copenhagen in terms of fundamental human rights and minority rights on which 
the EU insists. This has been confirmed by the latest European Commission reports from April 2018, which state that B\&H has built a complex institutional structure that remains ineffective and is subject to different interpretations (European Commission, 2018, 4). Furthermore, the Court used this opportunity to confirm the fundamental rule of international law implying that obligations assumed at international level cannot be avoided by invoking the contrary norms of domestic law, including Constitutional Law (Kulenović, Hadžialić-Bubalo, Korajlić, 2011, $3)$. This imposes the necessity of amending the Constitution. However, this judgment is not only significant in terms of the obligation to adjust provisions of the Constitution of $\mathrm{B} \& \mathrm{H}$ to the European Convention. The judgement is also used as a reason for analysing several aspects of the constitutional system of $\mathrm{B} \& \mathrm{H}$, in which non-constituent peoples in $\mathrm{B} \& \mathrm{H}$ are limited or excluded from political decision-making procedures by ethnocratic regimes, thus undermining the generally accepted elements of statehood (Kulenović, Hadžialić- Bubalo, Korajlić, 2011,3). When B\&H signed the EU Accession and Stabilization Agreement in 2008, its implementation was postponed because the European Court of Human Rights Decision in the Sejdić-Fincicase was not yet implemented. Considering the attempt to enforce the decision by adoption of an amendment to the Constitution of B\&H, which lasted from 2009 to 2014, was unsuccessful, the Agreement was ratified not earlier then in 2015. Only then, thanks to the reforms of the institutions of B\&H (Border Service Agency, Intelligence and Investigation Services, and Police Reform- partly) (Pejanović, 2017, 6), the EU looked through B\&H's fingers, so the Agreement was ratified. The Parliamentary Assembly of B\&H failed to reach a consensus for implementation of the judgement during the abovementioned period. Proposals for amendments to the Constitution were discussed outside the Parliamentary Assembly, among the party leaders, thus usurping the power of the Parliamentary Assembly (Pejanović, 2015, 145). This violated B\&H's legal and democratic requirements, which correspond to the main political criteria of the EU adopted in Copenhagen. Therefore, B\&H's integration process was suspended from 2008 to 2015. This supports the statements given in the previous chapters on a non-functional setup of the state of $\mathrm{B} \& \mathrm{H}$, which is governed by ethnic political parties. Instead of parliamentary democracy, B\&H's Government is a form of particracy where one or more political parties dominate the political process (Pejanović, 2014, 25). It is important to note that the European Court of Human Rights did not offer any detailed guidelines or time limit for enforcement of the judgement (Kulenović, Hadžialić-Bubalo, Korajlić, 2011, 3), which may be entirely wrong when it comes to specific situation such as Bosnia and Herzegovina. In other words, it has already been seen in the post-Dayton years that there is a tendency to destabilize the Bosnian-Herzegovinian society and the social development of $\mathrm{B} \& \mathrm{H}$, every time there is a delay in the European integration process (Pejanović, 2017, 7). Without the development of European integration there will be no favourable internal integration in B\&H and its stability (Pejanović, 2017, 7). This indicates how much important is European integration for B\&H and partially proves the first hypothesis. However, given the dominant political 
constellation in $\mathrm{B} \& \mathrm{H}$, it seems that Eurosceptics are quite right when they argue that the application for EU membership was only declarative as the political elites in B\&H have not yet implemented any substantive reforms or tried to deal with any challenges on B\&H's path to the EU (Topčagić, 2016, 2). This is contrary to the official standpoint of the Ministry of Foreign Affairs of B\&H about the political consensus and the desire to join the EU. The current political constellation in B\&H reveals a crisis in political control because the ruling parliamentary parties are unable to achieve a consensus on the development of the state aimed at achieving its economic and political sustainability and getting a green light for the start of accession negotiations. The crisis stems from the fact that national parties, which, as a coalition, manage state resources, have built their positions on an ethnic basis and they have different ethno-national politics (Pejanović, 2017, 10). Parliamentary majority is not achieved based on a program coalition but rather partnership (Pejanović, 2017, 10). This implies that the Government is formed only for the sake of power, without a concrete course or a common idea that would lead the country in the right direction, because in the territory of Bosnia and Herzegovina, ethnic political parties have quite contradictory opinions about how to manage the state. Consequently, it could be assumed that the time will continue to run until reforms take place. This is confirmed by the opinion of the European Commission on the functional setup of the B\&H's Parliament. The Reform Agenda affected relationships between the dominant coalition parties, leading to a slowdown in the implementation of reforms (European Commission, 2018, 4). Insisting by certain delegates to adopt voting mechanism provisions that are not in compliance with the EU standards continues to prevent the Stabilization and Association Parliamentary Committee to adopt the Rules of Procedure and to finally commence with the board meetings (European Commission, 2018, 4). However, such a situation generates more and more problems, which can be resolved once the political problems are resolved. Political monopoly, without adequate competition, like the economic monopoly, is ineffective in its essence. Many reforms cannot be implemented because no agreement can be reached by the dominant coalition parties. Not to say that energy, employment or public finance management strategies are yet to be adopted (European Commission, 2018, 5).

The Constitution of B\&H does not allow citizens who do not declare themselves Bosniaks, Croats or Serbs to run for the Presidency or the House of Peoples of the Parliamentary Assembly (European Commission, 2018, 4). The case of Pilav v. $\mathrm{B} \& \mathrm{H}$ also illustrates issues that arise from the Constitution where Bosniaks and Croats from Republic of Srpska are unable to run for elections in the Presidency or the House of Peoples even though they are members of the constituent peoples, as well as Serbs from the Federation of Bosnia and Herzegovina (Ured zastupnika Republike Hrvatske pred Europskom sudom za ljudska, 2016, 54). Although this case differs from the case of Sejdić-Finci, as it is about a member of a constituent people, the European Court of Human Rights decided that the exclusion of the applicant from the B\&H Presidency election was based on ethnic origin and 
residence, which is a violation of Article 1 of Protocol12 (Ured zastupnika Republike Hrvatske pred Europskom sudom za ljudska, 2016, 54). Another case (Zornić v. B\&H) illustrates the issue of discrimination in B\&H elections. Mrs. Zornić was unable to run for elections in the House of Peoples of B\&H because she did not declare herself as a member of any ethnic group (European court of human rights, 2018, 1). The Court found that this case was identical to the earlier case of Sejdić-Finci, since Mrs. Zorić was unable to run for elections based on her ethnic identity. The Court concluded that the continued inability of candidates to run for elections did not have an objective and reasonable justification, which makes those provisions of the Constitution discriminatory. The statements on constitutional incompatibility with the political criteria are herewith proved, but there is no end to the problems of electoral legislation in $\mathrm{B} \& \mathrm{H}$. The next chapter will investigate other issues.

\subsection{Case of Croats in B\&H}

The above-mentioned court cases, which speak of violation of democratic principles, human rights and minority rights in $\mathrm{B} \& \mathrm{H}$, are not the only problems faced by the Bosnian-Herzegovinian society. This chapter discusses position and equality of constituent peoples, especially Croats, when running for elections. According to some authors, the Sejdić-Finci judgment opened the Pandora-box (Krešić, 2014, 86; Rudolf, 2011, 225). Since the Court stood in defence of the rights of other peoples in $\mathrm{B} \& \mathrm{H}$, that opened the case of Croats in $\mathrm{B} \& \mathrm{H}$ and the fact that since 2006 Croats have been unable to choose their legitimate representative in the Presidency of B\&H (Krešić, 2014, 86), although they are one of the three constitutive nations. It appears that members of the Presidency of B\&H are directly elected from their entity, which would be in line with federalism, but this is not the case in B\&H (Krešić, 2014, 86). In other words, elected representatives represent the constituent peoples who voted for them. Article V-1(a) of the Constitution stipulates that Members of the Presidency shall be directly elected in each Entity (with each voter voting to fill one seat on the Presidency) in accordance with an election law adopted by the Parliamentary Assembly (Krešić, 2014, 86). However, in $\mathrm{B} \& \mathrm{H}$, a bigger nation can vote for a presidency member who belongs to another constituent people (in this case, the Federation of $\mathrm{B} \& \mathrm{H}$ ), and, in this way, voters can select two candidates from two constituent peoples (Krešić, 2014, 86). Each voter has only one vote, but they are not divided into national electoral bodies when voting. Therefore, presidency members only formally represent their entities, having in mind that they are elected by all voters in each entity (Krešić, 2014, 86). The fact that voters in the Federation of B\&H elect two presidency members leads to a discovery that the electorate is indeed divided on the national basis (Krešić, $2014,86)$. Such a form of election enables bigger nation to influence the election of a presidency member from a smaller nation in Federation of B\&H (Krešić, 2014, 86). Although this did not happen in the first ten years after the war, the elections in 2006, 2010 and the 2018 elections have shown that this can occur in practice. 
B\&H's population should be considered based on ethnic identity according to the latest population list, where of the total number of population in $\mathrm{B} \& \mathrm{H}(3,531,159)$, Bosniaks make $50.1 \%$ or $1,769,592$, Croats make $15,4 \%$ or 544,780 , Serbs make $30.8 \%$ or $1,086,733$, whereas others make $3.7 \%$ or 130,054 (Popis stanovništva u Bosni i Hercegovini, 2013). When considering the cause of post-election crises, the answer can be found in this statistic. B\&H is composed of three constituent peoples different in number. When using the rule of one person, one vote, Bosniaks as the biggest ethnic group could easily become the absolute hegemony in B\&H (Rudolf, 2014, 225). However, B\&H as a state is based on three constitutive and constituent or equal peoples and current form of elections violates rights of nations. The 2018 European Commission Report suggests that the electoral law framework needs to be amended urgently to guarantee adequate elections in October 2018 (European Commission, 2018, 2). Political leaders in B\&H must assume responsibility and find an adequate solution for elections in the Federal House of Peoples. However, no change in the electoral law has yet been made. The Constitutional Court Decision from 2010 to respect fundamental democratic right of citizens of Mostar to vote in local elections is still pending for its enforcement (European Commission, 2018, 2). Here, one should recall the starting point of the paper that EU is not a product of force or domination, but cooperation that was built over a period of decades and a free will of governments and peoples who had decided to unite to guarantee peace and justice and abandon nationalist aspirations. $\mathrm{B} \& \mathrm{H}$ should also follow the idea of European unity and find a way to fulfil fundamental democratic rights of all its citizens. Negligence of democratic principles and human rights means violation of constitutional foundations of the state of B\&H based on equality for all three constituent peoples. This issue could seriously slow down the European integration process. EU institutions are warning of the necessity of improving and expanding the rights of constituent peoples and national minorities, as well as all other $\mathrm{B} \& \mathrm{H}$ citizens. It can be concluded that without progress in integration processes the integrity of $\mathrm{B} \& \mathrm{H}$ is being questioned, which proves the first hypothesis (H1). On the other hand, solving political issues in B\&H is not just about to overcome obstacles in the integration processes (in terms of fulfilment of the political criteria), but it has implications on B\&H's economy. The Copenhagen economic criteria regulate a functioning economy of a country that should be considered regardless of EU integration; especially bearing in mind that EU membership is the will of the people of Bosnia and Herzegovina. The next chapter will discuss the economic criteria.

\section{PROBLEMS ENCOUNTERED BY B\&H IN FULFILMENT OF ECONOMIC CRITERIA FOR ACCESSION TO THE EU}

The previous chapters have shown that the most critical are the Copenhagen political criteria on B\&H's path to the EU integration. The analysis confirmed that there is an issue with the Constitution of $\mathrm{B} \& \mathrm{H}$ and that there are political problems that arise from the lack of consensus between ethnic political parties and their 
inadequate action in reforming the Bosnian-Herzegovinian society into a modern European society that will rely on pluralism and democracy, rule of law and other European values. The constitutional issues also reflect on the economic situation in $\mathrm{B} \& \mathrm{H}$. The Dayton Constitution in its structure is irrational and expensive, since each of the cantons in FB\&H, as well as the entities, has its own parliament and government, together with the existing two-house parliament system and government at the state level (Pejanović, 2014, 25). Such huge administration requires $6 \%$ of total funds (Pejanović, 2014, 25), while, on the other hand, inadequate funds are allocated for health care, science and social welfare. It is the assumption of the author that the economic crisis in B\&H is caused largely by lethargic political action and problematic constitution, which is far from meeting the economic criteria for accession to the EU. The paper will illustrate it through a few examples.

The first example describes the situation in 2013 where no agreement was reached on the continuation of B\&H's integration when EU and the international community decided to react. In May 2013, Doris Pack, EU Reporter for B\&H proposed amendments to the European Parliament Resolution on the progress of $\mathrm{B} \& \mathrm{H}$ in the EU Accession Process, suggesting suspending Bosnia and Herzegovina's membership of the Council of Europe as well as aid from the European Union pre-accession funds and the interim trade agreement between B\&H and the EU (Krešić, 2014, 87). Explaining her motion to punish B\&H, Doris Pack cited the inability of the Bosnian political leadership to agree on the implementation of a European Court of Human Rights ruling to eliminate from election legislation discriminatory provisions against national minorities (SejdićFinci case) (Krešić, 2014, 86). Although the amendments were not adopted and were more related to political criteria, B\&H could lose funds needed to improve its political and economic situation. According to the European Commission Report of April 2018, since 2013 to today, political awareness in Bosnia and Herzegovina is raising very slowly. The report states that achieving a consensus on economic policy is significantly impeded by frequent political blockades and lack of political will (European Commission, 2018, 30). Despite the general acceptance of the main principles of market economy, short-term and frequent political disputes lead $\mathrm{B} \& \mathrm{H}$ to delays and discontinuation of the implementation of long-term reform projects (European Commission, 2018, 30). Such a political situation has had a major impact on the situation in B\&H during 2017. The implementation of Reform Agenda and The Three-Year Stand-By Arrangement approved by the IMF in September 2016 significantly slowed down towards the end of 2017, after some positive events that occurred in the beginning of the year, due to the political situation in the country (EU Commission 2018 Assessments, 2018, 45). By the end of 2017 and early 2018, B\&H finally adopted amendments to the Excise Duties Act, which resulted in the first review of the IMF Program. The medium-term frameworks of macro-fiscal policies and structural reform program aimed at ensuring competitiveness and inclusive growth, defined by the Economic Reform 
Program $^{1}$, have been partly implemented in May 2017 (EU Commission 2018 Assessments, 2018, 45). The submission of the Economic Reform Program for May 2018 was postponed. Significant weaknesses in administrative co-ordination and cooperation, as well as policy formulation, were noted (EU Commission 2018 Assessments, 2018, 45). The described situation illustrates to what extent political frictions in the country reflect on fulfilment of the Copenhagen criteria on its path to the European membership. The next chapter will discuss the economic criteria.

\subsection{Level of development of B\&H's economy}

Before analysing current situation in $\mathrm{B} \& \mathrm{H}$ in terms of fulfilment of the economic criteria set up by the EU on its path to the membership, it is necessary to give a brief description of the economic criteria. The economic criteria for EU accession reflect a functioning market economy and the capacity to cope with competition and market forces (Palánkai, 1997, 53). The whole process of accession negotiations depends on meeting the economic criteria and implementing the necessary reforms. Reforms imply a minimum level of competitiveness in the main sectors of the candidate countries, including compliance with the criteria at a level at which government policies and legislation affect competitiveness (such as trade policy, competition policy, government aids, support to small and medium-sized enterprises) and trade integration with the EU before enlargement (quantity and type of goods exchanged with Member States) (Hodžić, 2012, 84). Therefore, meeting the EU accession criteria for B\&H should be viewed as the goal of transition into a functioning market economy, and not just a prerequisite for EU membership (Hodžić, 2012, 84). Implementing its institutional and structural reforms will be a lengthy process for B\&H regardless of its entry into the EU. Having in mind constant political disputes discussed in the previous chapter, transformation of B\&H's economy into a functioning market economy will last even longer.

\subsection{Problems of transition of $B \& H$ into a functioning market economy}

Current B\&H's economy is a supporting argument for the statements outlined at the end of the previous chapter. B\&H's economy is characterized by absence of real structural convergence, especially when it comes to its functioning market economy and competitive capacity (Hodžić, 2012, 83). The latest European Commission Report of April 2018 on B\&H's economic development and competitiveness highlights that $\mathrm{B} \& \mathrm{H}$ has made some progress but is still at early stage of building functioning market economy (European Commission, 2018, 30). Some improvements of the business environment have been achieved and the

\footnotetext{
${ }^{1}$ Each country that makes part of the EU accession process is obliged to prepare annual Economic Reform Programs, which define the medium-term frameworks of macro-fiscal policies and structural reform program aimed at ensuring competitiveness and inclusive growth. Economic Reform Program forms a basis of political guidelines specific to each country.
} 
financial sector has been strengthened (European Commission, 2018, 30). The following key issues remain unsolved: weak rule of law, poor business environment, fragmented and inefficient public administration, major labour market imbalances, poor education system, weak institutional capacities, and an unsupportive investment climate (European Commission, 2018, 30). In addition, the informal economy or grey economy remains a major factor that hampers the overall economic performance. Its consequences are manifested in tax evasion, market distortion, unfair competition, lack of social protection and insurance. Despite the intensified measures to combat the informal economy, it remains significant and accounts for about $25 \%$ of GDP. This high level of informal economy requires rates for taxes and social security contributions to be higher than would be otherwise necessary. This also adds to a significant fiscal burden affecting B\&H's competitive advantage at the international level (European Commission, 2018, 32). Furthermore, a weak rule of law and inadequate judicial system remain the key weaknesses of B\&H's economy where little progress has been made (European Commission, 2018, 32). There are still problems with contract enforcement, difficulties in settling commercial disputes and issues with establishing property rights (a low degree of real estate registration in some areas) (European Commission, 2018, 32). The issue of independence of regulatory and supervisory organizations remains unresolved (European Commission, 2018, 32). Although the state budget has recorded a slight surplus of funds, the quality of fiscal management remains very low. During 2017, public finances recorded a growth in revenue, reflecting steady growth in production, as well as improved tax collection measures. At the same time, government spending on public sector salaries remained the same (European Commission, 2018, 32). Despite improving the financing of the pension system, the overall quality of public sector management is exceptionally low especially in the health care sector and poor targeting of social transfers (European Commission, 2018, 32). One of the key issues remains the slowed down or delayed implementation of reforms aimed at improving efficiency of public expenditure. Although B\&H's public debt dropped slightly in 2017 and stood at $38 \%$ of GDP by the first half of the year, it is partly a reflection of difficulties in accessing foreign capital markets (European Commission, 2018, 32). Macroeconomic policy takes time to implement due to slowed down reforms and lack of adequate medium-term guidelines or goals (European Commission, 2018, 32). The macroeconomic stability is maintained, but the pace of implementing reforms is too slow to achieve concrete progress in the country (European Commission, 2018, 32). Concerning the business environment, the Report highlights that regulations on entry and exit to and from the market have slightly improved, but many barriers remain (European Commission, 2018, 32). Some improvements have been achieved to reduce administrative burden and simplify business registration and support foreign investors (European Commission, 2018, 32). Although certain, but still minimal, advances in improving the business environment have been achieved, compared to other countries, the business environment in $\mathrm{B} \& \mathrm{H}$ has even worsened, reflecting a slow 
implementation of structural reforms (European Commission, 2018, 32). The barriers to entry and exit to and from the market are still too many and time consuming thus under mining the attractiveness of $\mathrm{B} \& \mathrm{H}$ as a potential market for an international business (European Commission, 2018, 32).

The Government's role in B\&H's economy is still very important, which conflicts with a functioning market economy. Despite efforts to reduce its impact, public expenditures still account for more than $40 \%$ of GDP, generating $22 \%$ of value added and employing $26 \%$ of the workforce in the country (European Commission, 2018, 33). State-owned enterprises as well as government aids and guarantees remain heavy burden on public finances and taxpayers (European Commission, 2018, 33). It can be concluded that the privatization process has not been completed. Attempts to privatize public companies were usually unsuccessful. A thorough analysis of the two local telecommunications companies was conducted on their respective privatization paths (European Commission, 2018, 33). Strategic sectors such as energy, transport, (and telecommunications in Federation of $\mathrm{B} \& \mathrm{H}$ ) are still under poorly managed and often involve ineffective state-owned companies (European Commission, 2018, 33). Continuing with the process of privatization of state-owned enterprises could stimulate competition and improve the quality of services and reduce the burden on public finances (European Commission, 2018, 33), again pointing out that the privatization process has not been completed. More developed European and world economies that are still feeling the effects of the economic and financial crisis of 2007/2008 still not seeing the growth they saw before the crisis can be viewed as a very interesting field for research into structural reforms and policies as mainstream theoretical and practical economic science. When comparing those economies with Bosnia and Herzegovina, it can be concluded that $\mathrm{B} \& \mathrm{H}$ is at early stage of implementing structural economic reforms and that it first needs to resolve its political and institutional issues. However, it seems that B\&H has not yet started to cope with implementing its structural reforms when compared to more developed countries in this region and at the global level. The above-mentioned statements correspond to B\&H's key weaknesses to be taken into consideration in achieving long-term growth and development. The European Commission has proposed the following measures:

- Strengthening political intentions to foster the implementation of structural reforms through coordination and cooperation across various levels of government,

- Improving the quality of public financial management systems, adjusting and improving targeting of social expenditures aimed at developing and improving the quality of life;

- Increasing the availability and reliability of statistical data by applying European and international standards (European Commission, 2018, 30). 
The key to B\&H's economic development is the political will and the ability of policy-makers to establish an effective and efficient public spending system. It is important to note that $\mathrm{B} \& \mathrm{H}$ has not yet established an independent and effective IPA funding management system (Maletić, Kandžija, 2018, 250). This is one more motive for political synergy and responsibility, as IPA funding could be used to achieve improvements in B\&H's social and economic structure. EU remains responsible for financial support, which means that the Delegation of the EU is the contracting authority and is responsible for implementing projects financed by IPA and coordinating with other Member States (Maletić, Kandžija, 2018, 250). The task of $\mathrm{B} \& \mathrm{H}$ is to establish effective and efficient coordination mechanisms for issues related to the EU. Also, it is necessary to set up a national strategy, which is a key prerequisite for IPA funding (Maletić, Kandžija, 2018, 250). B\&H must show improvements in establishing efficient institutional structures for using preaccession assistance instruments in rural development (IPARD) (Maletić, Kandžija, 2018, 250). It is necessary to point out that $\mathrm{B} \& \mathrm{H}$ has not yet adopted a rural development national strategy (Maletić, Kandžija, 2018, 250). The aim is to further enhance the harmonization process of national strategies for agriculture, food industry and rural development, as well as production of wine and organic food (Maletić, Kandžija, 2018, 250). Administrative and coordination capacities in agricultural and rural development, which include government aid measures, also need to be reinforced (Maletić, Kandžija, 2018, 250). Transition is a slow and complex process where time is crucial. The global economic environment is in a constant change in a competition in which $\mathrm{B} \& \mathrm{H}$ has not yet taken part. B\&H's transition process is further complicated by constant political tensions, reflecting in slowed down or delayed implementation of structural policies and reforms. This is a supporting argument for the assumption of negative impact of political frictions on B\&H's economy development and proves the second hypothesis (H2). Due to the absence of political integration, B\&H was not able to define a consistent transition model. Other negative effects on B\&H's development are inactive society, inherited from the era of socialism, economy which suffers devastating impacts during and after a time of war and strong interference of the international community in its internal politics (Tomaš, 2013, 106).This implies that the Dayton Agreement has only partially defined the transition model. The international organizations have applied a model of economic transition derived from the neoliberal ideology of aggressive capitalism, believing that the market economy, the single currency and entrepreneurial freedom with strong financial support will soon reduce the contradictions in the Bosnian society and lead to progress and economic integration in the country (Tomaš, 2013, 106). This recipe did not seem to fit the Bosnian reality (Fischer, 2006, 447). Political differences in the country are far deeper than previously thought and the international community carries a part of the responsibility for the current situation. However, all that has been mentioned so far is not a reason why $\mathrm{B} \& \mathrm{H}$ should not cope with its problems and try to turn its weaknesses which arise from political differences in to strengths. It first involves identifying reasons a problem exists. Critical issues in B\&H's 
economy that concern its competitiveness need to be identified and analysed to setup an adequate and successful strategy, which will be discusses in the following chapters.

\subsection{Effects of current $B \& H$ 's economy on the labour market}

Before addressing the concrete problems facing $\mathrm{B} \& \mathrm{H}$ with regard to its competitive advantage, it is extremely important to look at and analyse the labour market that is quite difficult. The impact of the socio-economic crisis in Bosnia and Herzegovina is best described by statistics of the Labour and Employment Agency of $\mathrm{B} \& \mathrm{H}$, according to which in the middle of 2018 there were 448,071 or $35.9 \%$ unemployed people (Agencija za rad i zapošljavanje Bosne i Hercegovine, 2018). The number of unemployed people decreased compared to 2017 (486,309 or $39.4 \%$ ) (Agencija za rad i zapošljavanje Bosne i Hercegovine, 2018). According to the European Commission Report, the percentage of unemployed people in 2017 was $38.7 \%$, fell down by $6.1 \%$ compared to 2016 (European Commission, 2018, 33). B\&H's labour market should be viewed in terms of differences which arise when comparing registered unemployment rates and survey data showing significant weaknesses in statistical records. Also, these data reveal demographic issues and weaknesses in professional education and training (European Commission, 2018, 33). The question is whether the increase in employment rates is the result of registered employment in $\mathrm{B} \& \mathrm{H}$ or economic migration. In other words, the official website of the Labour and Employment Agency of B\&H offers information on jobs abroad. According to the Federal Institute for Pension and Disability Insurance, the number of retired workers in B\&H in August 2018 was 412,815 with a very low average pension in the amount of 400,39 KM (FZ MIO Federalnog zavoda za mirovinsko i invalidsko osiguranje, 2018). According to the Fund for Pension and Disability Insurance of Republic of Srpska, the number of retired workers in August 2018 was 304,722 with an average pension even lower than in FB\&H 366 KM (Fond PIO RS - Fonda za penzijsko i invalidsko osiguranje Republike Srpske, 2018). When the entity statistics sum up, a total of 717,537 retired workers are obtained at the state level. According to the Agency for Statistics of B\&H, the total number of employed people in B\&H in July 2018 was 805,715 (Agencija za statistiku $\mathrm{BiH}, 2018$ ). The number of retired workers is drastically approaching the number of employed persons, whereas the number of unemployed people has exceeded half of the total number of employed people. When the number of retired workers and unemployed persons is summed up, a total of 1,130,352 is obtained, which exceeds the total number of employed people for 324,637 . Here it is necessary to make a short digression and consider availability of statistical data that is shared by entities. In other words, statistical data are not available at the state level as was recommended in the latest European Commission Report. Such a high unemployment rate is indicative of structural unemployment. Structural unemployment is a result of the transition and transformation of the national economy, migration trends and other challenges in the labour market (Kandžija, Pucar, Tolić, 2016, 92). Although high 
unemployment rate is the result of economic transition, especially in the sectors of large former social and public enterprises, B\&H is also facing unemployment of young people (Kandžija, Pucar, Tolić, 2016, 92). According to the Federal Bureau of Statistics of $\mathrm{B} \& \mathrm{H}$, the unemployment rate in most cities is extremely high, which also shows that unemployment is the biggest weakness in this region (Kandžija, Pucar, Tolić, 2016, 92). All the figures given above speak best about the economic and social situation in $\mathrm{B} \& \mathrm{H}$, which is crying for change, but also about the fact that the change will be hard.

\subsection{Macroeconomic situation of $B \& H$}

According to the European Commission Report, the macroeconomic situation of B\&H remained stable in 2017, but far below its potential (European Commission, 2018,31 ). Production growth remained stable with an average increase of $2.5 \%$ per year over the past five years. The driving force of growth was domestic demand, especially in personal consumption expenditures on the account of a stable inflow in the labour-force renewal rate and low inflation rate of real household disposable income (European Commission, 2018, 31). Unlike the recession period from 2010 to 2014 characterised by a very low economic growth of $-1.1 \%$ in 2012 or $1-2 \%$ (in some sources 2.5\%) in 2010, 2011, 2013, and 2014 (Kandžija, Pucar, Tolić, 2016, 83 ), the situation has slightly improved but has not changed significantly. Economic growth in 2017 resulted from increased demand, which gave an additional boost to B\&H's economy (European Commission, 2018, 31). At the same time, domestic and foreign investments remained very low $(2.2 \%)$ due to poor business environment and high degree of political uncertainty (European Commission, 2018, 31). GDP per capita was around $32 \%$ of the EU-28 average in 2016, which is only slightly higher than the 2012 figure of 32\% (European Commission, 2018, 31). Such a low economic activity in B\&H stems from its economic structure, so it needs to be analysed more closely. Since the economic structure has not changed significantly, some older but more accessible data from 2014 will be used for analysing, where $33.7 \%$ of a total of active enterprises in B\&H $(26,395)$ were located in 4 larger cities: Sarajevo (4,390), Banja Luka $(2,169)$, Tuzla $(1,216)$ and Mostar $(2,169)$, revealing disparities in development between urban and rural environments. A real picture of economic activity in $\mathrm{B} \& \mathrm{H}$ can be obtained by comparing the number of enterprises per 1,000 of inhabitants with other countries, which was 7 enterprises per 1,000 of inhabitants (Kandžija, Pucar, Tolić, 2016, 86). If this number is compared with more developed neighbouring countries, like Croatia, which has 27 active small and medium-sized enterprises per 1,000 inhabitants, and is amongst the least developed countries of the EU, the disparity in development is more than obvious and B\&H lags behind Croatia for three times (Kandžija, Pucar, Tolić, 2016, 86). Furthermore, in terms of sector structure, $35.2 \%$ of all companies in B\&H deal with trade, then construction, transportation, wood processing and services. Only one manufacturing industry (metallurgy) is among the top five sectors by number of active enterprises 
(Kandžija, Pucar, Tolić, 2016, 86). Trade with the largest number of active enterprises makes the largest share in B\&H's total income or 48\% (Kandžija, Pucar, Tolić, 2016, 90). Although metallurgy is the first among the top five manufacturing industries by the number of active enterprises, the food industry ranks first by revenue (2.06 billion $\mathrm{KM})$, followed by metallurgy with 1.76 billion $\mathrm{KM}$ of revenue and wood processing industry with KM 1.2 billion of revenue (Kandžija, Pucar, Tolić, 2016, 90). B\&H's economic structure is extremely unfavourable, where trade and services make $48.3 \%$ of the total structure with 12,763 active enterprises out of a total of 26,395 , and production is characterised by low value added products. Such an economic structure affects imports of significantly more expensive goods (on average 60\% more expensive by $1 \mathrm{~kg}$ ) than exported (Kandžija, Pucar, Tolić, 2016, 85) driving the trade deficit at a high level. The above suggests that $\mathrm{B} \& \mathrm{H}$ exports raw materials (leather, wood, metal) and imports finished products. Such an economy is not sustainable in the long run. The European Commission Report for 2017 highlights that B\&H's trade deficit dropped by $5.1 \%$ in 2016 or by $4.7 \%$ in 2017 , on the account of export activity increase, lower import prices and tourism activity increase (European Commission, 2018, 31). However, higher consumption-based imports are still holding trade deficits very high at $23.6 \%$ of GDP (European Commission, 2018, 31). The trade sector holds the largest share of B\&H's economy and generates the highest portion of total revenue, but also records a profit rate of only $2.9 \%$ (Kandžija, Pucar, Tolić, 2016, 96). On the other hand, a significantly smaller ICT sector is ranked fourth by total revenue and first by profit rate $(9.7 \%)$, which is an indicator of effective business management system and highest productivity rate (Kandžija, Pucar, Tolić, 2016, 96), but also reveals how important knowledge, and implementation of the knowledge acquired, is in production to achieve better economic results. In terms of value-added based productivity, B\&H's economy, which trade activity prevails, has no competitive ability to cope with competition and market forces on the European market. This might be the most critical problem in the future. The next chapter discusses the competition aspect of the economic accession criteria.

\subsection{B\&H's competitiveness}

After having conducted researches on competitiveness for nearly three decades, in 2004, the World Economic Forum (WEF) proposed its Global Competitiveness Index (GCI) as a universal index for measuring national competitiveness. The GCI index integrates the macroeconomic and microeconomic aspects of competitiveness into a single index (Parežanin, Jednak, Kragulj, 74 2014,). The latest WEF report proposes 12 categories - the pillars of competitiveness - that collectively make up a comprehensive picture of a country's competitiveness. GCI scores are based a set of institutions, policies and factors that determine the level of productivity of a country, which in turn sets the level of prosperity that the country can earn. The level of productivity determines the rates of return obtained by investments in an economy, which in turn are the fundamental drivers of its growth 
rates (World Economic Forum, 2017-2018, vvi). In other words, developing a more competitive economy will lead to generating faster economic growth. In the period from 2015 to 2016, when the world economy was emerging from the economic crisis (caused by the 2007/2008 financial crisis), B\&H was ranked very low on 111th according to the GCI (Kandžija, Pucar, Tolić, 2016, 98). When compared to Croatia, which ranked 77th or Greece, which ranked 84th, whereas both countries are amongst the least developed countries of the EU, it is evident that B\&H lags far behind the least developed European economies. WEF reports for 2017(World Economic Forum, 2017-2018, 66, 98, 130) confirm that B\&H has made some progress and ranked 103rd, whereas Croatia ranked 74th and Greece 86th. In 2018, B\&H ranked 91st, Croatia 68th and Greece 57th (World Economic Forum, 2018, $107,179,247)$. According to the WEF report, B\&H lags behind all the countries in the region: Albania ranks 76th (jumped 4 places compared to the previous year), Macedonia 84th, Montenegro 71st (jumped 2 places compared to the previous year) and Serbia 65th (jumped 5 places compared to the previous year) (World Economic Forum, 2018, 55, 336, 403, 499). In order to obtain a real picture of B\&H's competitiveness, it is necessary to explore all the factors that influence its position in the GCI ranking and compare it to Croatia as its first neighbour country and $\mathrm{EU}$ member in order to determine how much $\mathrm{B} \& \mathrm{H}$ lags behind in terms of competitiveness and which economic criteria need to be met for accession to the EU. Table 1 and Figure 1 compare competitiveness of B\&H and Croatia according to 2017-2018 Reports, while Table 2 and Figure 2 indicate data from 2018 Report.

Table 1. Twelve pillars of competitiveness for B\&H and Croatia2017-2018

\begin{tabular}{|l|c|c|c|c|c|}
\hline \multicolumn{1}{|c|}{ Pillars } & $\begin{array}{c}\text { B\&H } \\
(2017- \\
2018) \\
\mathbf{1 0 3}\end{array}$ & & & $\begin{array}{c}\text { Croatia } \\
(2017- \\
2018) \\
\mathbf{7 4}\end{array}$ & \\
\hline Subindex A: Basic requirements & 91 & & $<$ & 58 & \\
\hline Pillar 1: Institutions & 126 & & $<$ & 102 & \\
\hline Pillar 2: Infrastructure & 100 & & $<$ & 48 & Top 70 \\
\hline $\begin{array}{l}\text { Pillar 3: Macroeconomic } \\
\text { environment }\end{array}$ & 64 & Top 70 & $<$ & 60 & Top 70 \\
\hline $\begin{array}{l}\text { Pillar 4: Health and primary } \\
\text { education }\end{array}$ & 56 & Top 70 & $<$ & 44 & Top 70 \\
\hline Subindex B: Efficiency enhancers & 100 & & $<$ & 69 & \\
\hline $\begin{array}{l}\text { Pillar 5: Higher education and } \\
\text { training }\end{array}$ & 91 & & $<$ & 60 & Top 70 \\
\hline Pillar 6: Goods market efficiency & 126 & & $<$ & 99 & \\
\hline Pillar 7: Labour market efficiency & 123 & & $<$ & 107 & \\
\hline $\begin{array}{l}\text { Pillar 8: Financial market } \\
\text { development }\end{array}$ & 104 & & $<$ & 95 & \\
\hline Pillar 9: Technological readiness & 69 & Top 70 & $<$ & 43 & Top 70 \\
\hline Pillar 10: Market size & 97 & & $<$ & 77 & \\
\hline
\end{tabular}




\begin{tabular}{|l|c|c|c|c|c|}
\hline $\begin{array}{l}\text { Subindex C: Innovation and } \\
\text { sophistication factors }\end{array}$ & 119 & & $<$ & 99 & \\
\hline Pillar 11: Business sophistication & 115 & & $<$ & 82 & \\
\hline Pillar 12: Innovation & 123 & & $<$ & 106 & \\
\hline
\end{tabular}

Source: World Economic Forum, Global Competitiveness Index 2017-2018 edition, 2017

B\&H ranks among the top 70 countries in the following areas: macroeconomic environment, primary health care and technological readiness, while having a low rank in the areas of institutions, infrastructure, goods market efficiency, labour market efficiency, business sophistication and innovation (below 115th). B\&H ranked among the top 70 countries in three of the 12 categories of competitiveness measured. It ranked below the 115th place in 6categories, which are very important in terms of competitiveness such as institutions and infrastructure that have an important effect on foreign investment. Such a picture of B\&H's competitiveness reveals its key weaknesses and confirms the assumptions about the problems it is facing as discussed in previous chapters (institutional inefficiencies caused by political disunity, dysfunctional market economy as a result of unfinished transition process, slowed down or delayed implementation of reforms and infrastructure improvement due to the slow government response). On the other side, Croatia ranks among the top 70 countries in five of the 12 categories of competitiveness measured: macroeconomic environment, infrastructure, public health and primary education, higher education and training, technological readiness, and, unlike B\&H, Croatia never ranked below the 110th place. Although Croatia as well has its weaknesses in terms of institutional issues and labour market, it ranks 20 places higher in these categories of competitiveness. The biggest difference between these two countries is manifested in the areas of infrastructure, higher education and training, technological readiness, and business sophistication. Figure 2 shows competitive differences between the two countries and how much $\mathrm{B} \& \mathrm{H}$ lags behind Croatia. 
Figure 2. Comparing competitiveness B\&H vs. Croatia 2017-18

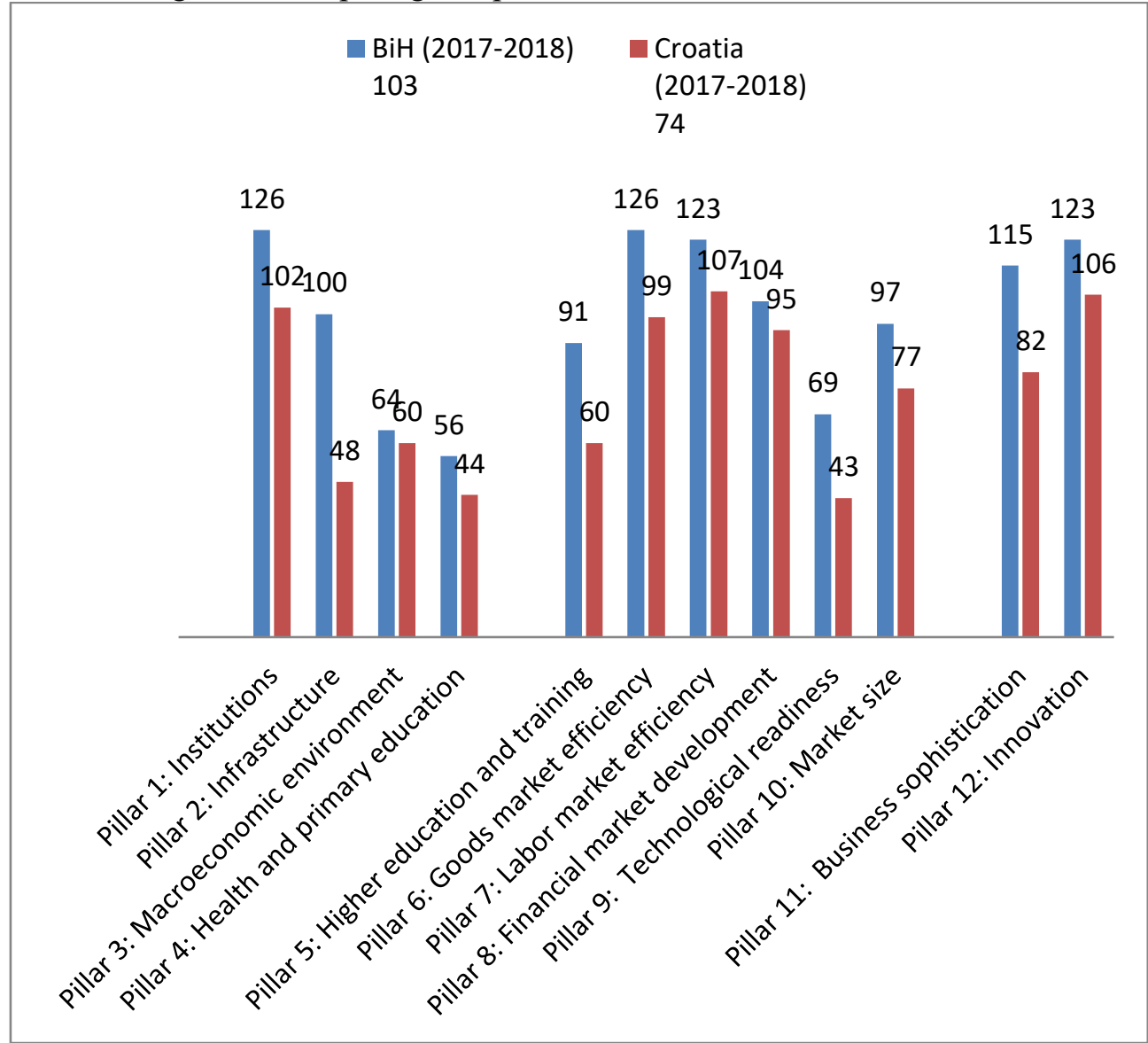

Source: World Economic Forum, Global Competitiveness Index 2017-2018 edition, 2017

Although both Croatia and Greece are among the least developed countries of the $\mathrm{EU}$, it is more useful to show a graphical representation of the gap of competitiveness between $\mathrm{B} \& \mathrm{H}$ and Croatia. $\mathrm{B} \& \mathrm{H}$ is approaching Croatia in terms of competitiveness, especially in areas of macroeconomic environment, health care and primary education, but still lags behind Croatia in all categories.

Table 2 and Figure 2 show changes in the global competitiveness scale and reveal that the countries have made some progress in 2018. WEF is making continuous improvements in measuring competitiveness, so it is easy to note that competitiveness categories differ from the previous report. The most problematic factors for doing business in B\&H are: inefficiency of government bureaucracy, corruption, tax rates, political instability and weak government, access to finance, tax regulations, restrictive labour regulations, crime and theft, poor working ethics, inadequately educated workforce, inadequate infrastructure, foreign exchange 
regulations, poor public health and inflation. The most problematic factors for doing business in Croatia are almost the same: inefficiency of government bureaucracy, corruption, tax rates, political instability and weak government, access to finance, tax regulations, restrictive labour regulations, crime and theft, poor working ethics, inadequately educated workforce, inadequate infrastructure, foreign exchange regulations and poor public health. The difference is that Croatia's innovation capacities are inefficient, while B\&H is fighting to have inflation under control.

Table 2. Twelve pillars of competitiveness for B\&H and Croatia 2018

\begin{tabular}{|l|c|c|c|c|c|}
\hline Pillars of competitiveness & $\begin{array}{c}\text { B\&H } \\
(2018) \\
\mathbf{9 1}\end{array}$ & - & & $\begin{array}{c}\text { Croatia } \\
(2018) \\
\mathbf{6 8}\end{array}$ & \\
\hline \multicolumn{1}{|c|}{ Enabling Environment } & - & & - & - & \\
\hline Pillar 1: Institutions & 111 & & $<$ & 74 & \\
\hline Pillar 2: Infrastructure & 89 & & $<$ & 36 & Top 70 \\
\hline Pillar 3: ICT adoption & 86 & & $<$ & 53 & Top 70 \\
\hline $\begin{array}{l}\text { Pillar 4: Macroeconomic } \\
\text { stability }\end{array}$ & 73 & & $>$ & 106 & \\
\hline \multicolumn{1}{|c|}{ Human Capital } & - & & - & - & \\
\hline Pillar 5: Health & 52 & Top 70 & $<$ & 51 & Top 70 \\
\hline Pillar 6: Skills & 87 & & $<$ & 65 & Top 70 \\
\hline \multicolumn{1}{|c|}{ Markets } & & & & & \\
\hline \multicolumn{1}{|c|}{ Pillar 7: Product market } & 106 & & $<$ & 71 & \\
\hline Pillar 8: Labour market & 112 & & $<$ & 96 & \\
\hline Pillar 9: Financial system & 83 & & $<$ & 62 & Top 70 \\
\hline Pillar 10: Market size & 99 & & $<$ & 78 & \\
\hline \multicolumn{1}{|l|}{ Innovation Ecosystem } & - & & - & - & \\
\hline Pillar 11: Business dynamism & 106 & & $<$ & 81 & \\
\hline Pillar 12: Innovation capability & 114 & & $<$ & 63 & Top 70 \\
\hline
\end{tabular}

Source: World Economic Forum, Global Competitiveness Index, 2018

The table shows that $\mathrm{B} \& \mathrm{H}$ is ranked among the top 70 countries in only one category - health, whereas Croatia is ranked among the top 70 countries in six categories: infrastructure, ICT adoption, health, skills, financial system and innovation capability. Interestingly, according to the latest report, $\mathrm{B} \& \mathrm{H}$ is macroeconomically more stable than Croatia. The data is represented graphically for better visual comparison (Figure 2: Comparing competitiveness B\&H vs. Croatia 2018). 
Figure 2. Comparing competitiveness B\&H vs. Croatia 2018

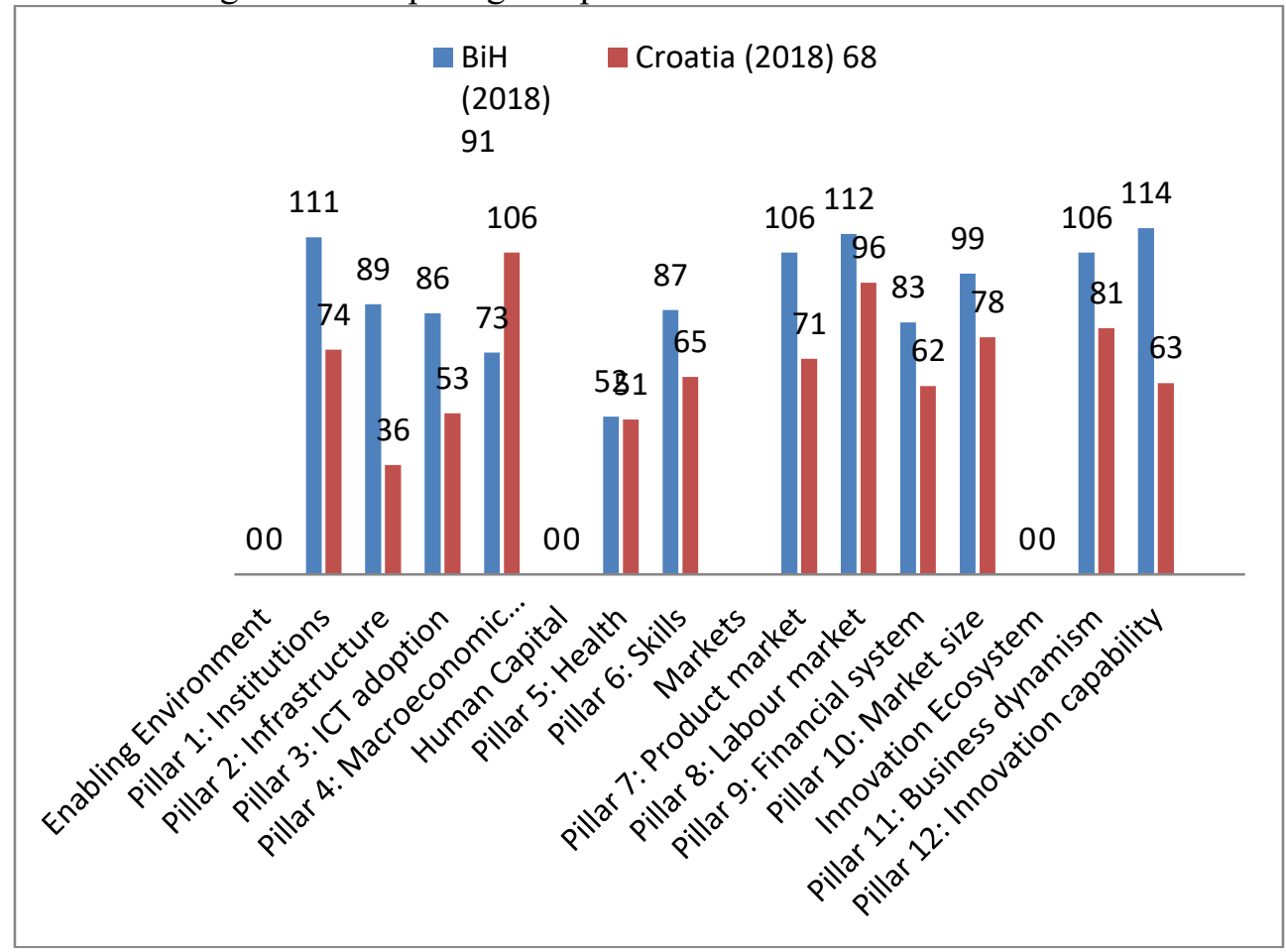

Source: World Economic Forum, Global Competitiveness Index, 2018

Figure 2 shows that even though $\mathrm{B} \& \mathrm{H}$ is approaching Croatia only in health category, its macroeconomic position is better than of Croatia. Both countries show some progress in the global competitiveness ranking, organized in 12 pillars of competitiveness, but the analysis reveals some weaknesses. B\&H's greatest weaknesses are: organized crime, poor reliability of police services, restrictive law regulations, regulatory burden, inefficiency of legislative framework in dispute resolution processes, low E-participation level, inadequate government orientation, inefficient protection of ownership and intellectual rights, low level of application of audit standards and reports, inadequate conflict of interest rules, poor road infrastructure quality, poor rail service efficiency, poor air traffic efficiency, poor maritime traffic efficiency, low mobile phone subscription, low mobile internet subscription, inadequate professional education and training, inadequate skills of graduates, shortage of skilled workers and lack of critical thinking in teaching (all subcategories below 100th). Croatia's greatest weaknesses are: low level of social capital, low level of judicial independence, restrictive law regulations, regulatory burden, inefficiency of legislative framework in dispute resolution processes, inadequate government orientation, inefficient protection of ownership rights, low level of application of audit standards and reports, inadequate debt dynamics, inadequate professional education and training, inadequate skills of graduates, 
shortage of skilled workers and lack of critical thinking in teaching, and insufficient level of digital skills (all subcategories below 100th).

The comparative analysis indicates that $\mathrm{B} \& \mathrm{H}$ is lagging too far behind the least developed EU countries (Croatia and Greece) and other countries in the region (candidates and potential candidates). Urgent efforts should be done to achieve improvements in the critical areas of competitiveness such as institutional system, infrastructure, health care, labour market, business dynamics, etc. The unfavourable political situation in $\mathrm{B} \& \mathrm{H}$, where the country's political elites go separate ways, is emerging as the biggest obstacle to the EU accession and economic development, and the recovery will be long and painstakingly slow.

\section{CONCLUSION}

Globalization is the connection of different parts of the world in a whole. Countries group for political and economic reasons. Small and developing countries are facing increasing challenges on their respective paths of prosperity. Considering their turbulent history and stormy present, and economy's uncertain future, in the author's opinion that is founded on research, the future of the countries of the Western Balkans lies in European integration. A united and prosperous EU serves as an example and provides a sort of control mechanisms for improving socioeconomic relations, preserving peace and maintaining stability in $\mathrm{B} \& \mathrm{H}$ and the entire Western Balkans region. B\&H, a country situated in the Western Balkans, has its potential for development and economic growth, but shows extremely slow progress in all the categories of competitiveness. As part of the EU, Bosnia and Herzegovina will be able to constructively use its potentials arising from its diversities, like the EU did in the middle of last century. EU has long supported the countries of the Western Balkans, including $\mathrm{B} \& \mathrm{H}$, on their respective integration paths. The EU has shown its initiative and willingness to accept these countries and has been providing development assistance from EU funds. In return, the EU insists that candidate sand potential candidates orient themselves around the task of building effective and functioning states, employing EU control mechanisms. The first condition in the integration process is fulfilment of the Copenhagen Criteria, which should be considered more as guidelines for building an effective, functioning state, not as obstacles on the path to EU accession. Bosnia and Herzegovina needs to make changes to improve its constitutional structure and institutional system to guarantee democratic rights of all its citizens, both constituent peoples and national minorities, as proved by testing the first hypothesis. Meeting the Copenhagen political criteria and achieving progress on its path to European integration is a precondition for achieving integrity and stability of Bosnia and Herzegovina. The major problem regards fulfilment of the political criteria due to a lack of political consensus and a lack of seriousness when it comes to try and achieve it. This is illustrated by the example of non-implementation of the Sejdić-Finci judgement, which is blocking B\&H's application for EU membership for almost ten years. Slowing down EU integration processes results 
in the destabilization of the $\mathrm{B} \& \mathrm{H}$, which emphasizes the importance of $\mathrm{B} \& \mathrm{H}$ becoming part of the EU. The European Court of Human Rights Decision in the Sejdić-Finci case has not yet been implemented and is the subject of all the reports of the European Commission for B\&H. Moreover, the latest report included similar cases of Pilav, Zornić and Šalaku v. Bosnia and Herzegovina, involving violation of democratic rights of the citizens of Mostar and indicating a growing dissatisfaction of the Croatian people for not changing the electoral law. Every election could trigger another crisis, which proves the first hypothesis on B\&H's integrity that must not be compromised by violating democratic rights of any of the three constituent peoples.

Furthermore, issues stemming from a lack of political consensus are reflected in the country as a whole and heavily affect B\&H's economy. Government spending is too high ( $6 \%$ of GDP) and does not tend to decrease. Functions of public administration institutions are not well integrated and interlinked, nor are they well aligned to justify such expenditure. Political instability is slowing down the implementation of structural reforms to create a favourable business and investment climate and revive economy. In this way, B\&H's economy is deprived of necessary resources from domestic and foreign sources to finance its activities. In addition, B\&H does not have its own mechanisms for managing absorption of pre-accession funds under the IPA, but pre-accession assistance is provided under the supervision of the EU institutions. Due to differences and disagreements existing between them, the political elites in $\mathrm{B} \& \mathrm{H}$ limit themselves to use the funds that are necessary for their homeland. Issues of corruption, black market and nontransparency strongly affect the country's competitiveness. These problems all stem from political instability and could be resolved once political consensus is reached and once the political elites demonstrate readiness to fulfil the political criteria to enable their country deal with its economic problems such as: large labour market imbalances, excessive deficit, unfavourable export structure, and slowed-down or delayed implementation of reforms in agricultural and industrial sector. The political elites in Bosnia and Herzegovina need to act responsible and seek to achieve overall consensus to enable their country make progress towards meeting the economic criteria for EU accession. In the second hypothesis, it has been proved that B\&H's political situation has negative effects on its economy in all its segments and tends to slowdown the implementation of urgent structural reform priorities. The practice shows that the process of implementation of structural reforms can be extremely difficult and lengthy, and could take almost 10 years to yield results, especially in education, which is one of B\&H's major issues. It can therefore be concluded that the leadership of this country must first agree on all major issues and try to solve the problems. However, it seems that $\mathrm{B} \& \mathrm{H}$ has not yet started implementing its reforms, as the current political stalemate is affecting the economy of the country and there is difficulty passing laws that satisfy the needs of the people. Almost 23 years after the war and the Dayton Agreement, $\mathrm{B} \& \mathrm{H}$ has not succeeded to construct a functioning market economy and achieve 
faster growth. Progress at raising competitiveness has been slow, showing weaknesses primarily in B\&H's institutional system, infrastructure, innovation, market efficiency, etc. The EU accession process based on the fulfilment of the political and economic criteria has revealed B\&H's weaknesses that need to be improved to become a functioning and competitive state, which is founded on the shared values of democracy, rule of law and market economy. The EU accession process should be considered as a stage of development on the path to European integration, which, as previously discussed, remains B\&H's strategic priority to maintain its integrity and stability. Given the current situation and all the problems facing Bosnia and Herzegovina, and the slow pace of structural reforms, it can be concluded that Bosnia and Herzegovina should take the instructions received from the European Commission seriously and urgently try to deal with its problems and difficulties to speed up the European integration process aimed at ensuring its integrity, stability and modern market economy.

\section{REFERENCES}

1. Agencija za rad i zapošljavanje Bosne i Hercegovine (2018): Mjesečno saopćenje (2018), in: Pregled stanja tržišta rada na dan 30. lipanj 2018. godine,

http://www.arz.gov.ba/statistika/mjesecni/default.aspx?id=3546\&langTag= hr-HR, (accessed 20 September 2018)

2. Agencija za statistiku BiH(2018): Demografija i socijalne statistike (2018), in: Zaposleni po djelatnostima, http://www.bhas.ba/index.php?option=com publikacija\&view=publikacija pregled\&ids $=1 \& \mathrm{id}=2 \& \mathrm{n}=\mathrm{Tr}$, (accessed 20 September 2018)

3. Aybet, G., Bieber, F., (2011), From Dayton to Brussels: The Impact of EU and NATO Conditionality on State Building in Bosnia \& Herzegovina, Europe-Asia Studies, Routledge, London Vol. 63, No.10, pp. 1911-1937

4. European Commission (2018): Commission Staff Working Document (2018), in: Bosnia and Herzegovina 2018 Report, pp. 2-40 (https://ec.europa.eu/neighbourhoodenlargement/sites/near/files/20180417-bosnia-and-herzegovina-report.pdf) (accessed 29 September 2018)

5. European Commission (2018): The EU Commission's 2018 Assessments, in: Progress towards Meeting the Economic Criteria for EU Accession, pp. 1-61, https://ec.europa.eu/info/publications/economy-finance/progresstowards-meeting-economic-criteria-eu-accession-eu-commissions-2018assessments en (accessed 21 September 2018)

6. European court of human rights (2014): in: Bosna i Hercegovina mora uspostaviti politički sistem za izbore bez diskriminacije, pp. 1-4 http://www.fcjp.ba/templates/ja avian ii_d/images/green/Presuda Zornic vs_BiH.pdf (accessed 12 October 2018) 
7. Europa (2016): EEAS, EU Delegations (2016), in: Zaključci Vijeća EU o zahtjevu Bosne i Hercegovine za članstvo u EU, http://europa.ba/?p=44832, (accessed 20 September 2018)

8. Europska unija (2018): in: Povijest europske unije - 2003, https://europa.eu/european-union/about-eu/history/2000-2009/2003 hr, (accessed 14 September 2018)

9. EUR-Lex (2018): Summaries of EU Legislation (2018) in: Accession criteria (Copenhagen criteria), https://eurlex.europa.eu/summary/glossary/accession criteria copenhague.html, (accessed 16 September 2018)

10. Fischer, M., (2006), Bosnia's Challenge: Economic Reform, Political Transformation and War-to-Peace Transition, in: Martina Fischer (ed.) 2007, Peace building and Civil Society in Bosnia-Herzegovina, Ten Years after Dayton, Lit-Verlag, Münster, pp. 441-470

11. Fond PIO RS - Fonda za penzijsko i invalidsko osiguranje Republike Srpske (2018): in: Statistički bilten - 2018, http://www.fondpiors.org/statisticki-bilteni/statisticki-bilteni-2018/, accessed 20 September 2018)

12. FZ MIO - Federalnog zavoda za mirovinsko i invalidsko osiguranje (2018): Statistika, in: Struktura penzija za 08/2018, https://www.fzmiopio.ba/index.php?option=com content\&view=article\&i $\mathrm{d}=65 \&$ Itemid $=68 \&$ lang $=$ ba $($ accessed 20 September 2018)

13. Hodžić, K., (2012), Quasi-macroeconomic stability and incertitude of real convergence of Bosnia and Herzegovina, EU enlargment perpective Inside and outside concepts, Proceedings from 1st International Conference „Economic System of the European Union and Accession of Bosnia \& Herzegovina ", Vitez, B\&H, pp. 81-100.

14. Kandžija, V., Cvečić, I., (2010), Ekonomika i politika Europske unije, Sveučilište u Rijeci, Ekonomski fakultet, Rijeka

15. Kandžija,V., Tomljanović, M., Kandžija, T., (2015), Possible economic effects of EU convergence instruments on Western Balkan countries, Absorption capacity of EU pre-accession programs in the Western Balkan countries, CEMAFI International Association, Nice, pp. 142-153

16. Kandžija,V., Pucar, S., Tolić, I., (2016), Competitiveness, Economic Growth, and Development of Bosnia and Herzegovina: From Matter to Spirit, From Ignorance to Knowledge, CEMAFI International, France, Nice

17. Karan, S., (2014), Oblik državnog uređenja Bosne i Hercegovine, Godišnjak fakulteta pravnih nauka, Banja Luka, No. 4, pp. 156-157

18. Krešić, T., (2014), Europska Unija i Bosna i Hercegovina, Hrvatska akademija znanosti i umjetnosti / Croatian Academy of Sciences and Arts,Adrias svezak, Zagreb, No. 20, pp. 83-89 
19. Kukić, S., Šavija, M., (2017), Geopolitičke i društvene postavke za ubrzanje integracije $\mathrm{BiH}$ u EU, Zbornik radova Geopolitičke promjene u Evropi i svijetu i položaj BiH, ANUBiH, Sarajevo, pp. 55-67

20. Kulenović, N., Hadžialić-Bubalo, I., Korajlić, M., (2011), Presuda Sejdić i Finci protiv Bosne i Hercegovine, Konkretne posljedice - prvi pregled, Sveske za javno pravo, Fondacija Centar za javno pravo, Sarajevo, Vol. 1, No. 1-2, pp. 1-33

21. Kuzmanović, R., (2002), Ustavno pravo, Banja Luka

22. Kuzmanović, R., (2004), Eseji o ustavnosti i zakonitosti, Banja Luka

23. Maletić, I., Kandžija V., (2018), The Accession Process and IPA Funds in Bosnia and Herzegovina - An Opportunity for Restructuring Public Spending and Convergence Towards the EU, Zbornik radova Ekonomskog fakulteta Sveučilišta u Mostaru, Mostar, No. Special Issue 2017, pp. 238267

24. Ministarstvo vanjskih poslova $\mathrm{BiH}$ (2015): in: Bosna i Hercegovina i Evropska unija, http://www.mvp.gov.ba/vanjska_politika_bih/multilateralni_odnosi/evrops ka unija/bih i eu/?id=32084, (accessed 14 September 2018)

25. Nakić, M., (2013), Europska Unija i Zapadni Balkan: Između želja i realnosti, Centar za međunarodne studije Hrvatske udruge za međunarodne studije, Visoka škola međunarodnih odnosa i diplomacije Dag Hammarskjöld, Euroavangarde d.o.o., Zagreb, Vol. 13., No.1., pp. 33-44

26. Palánkai, T., (1997), Meeting Kopenhagen EU membership criteria by Hungary: Functioning market economy and capaticy cope withe competitive pressures within EU, Proceedings from I st International Conference „Economic system of European Union and Adjustment of the Republic of Croatia ", Faculty of Economics Rijeka, Rijeka, pp. 52-68

27. Parežanin, M., Jednak, S., Kragulj, D., (2014), The Influence of the Knowledge-Based Economy of European Economies and Business, Innovative Management and Firm Performance: An Interdisciplinary Approach, Palgrave Macmillan, pp 68-90

28. Pejanović, M., (2014), Pretpostavke ustavne reforme u Bosni i Hercegovini tijekom pristupanja EU-u, Političke analize, Faculty of Political Science, Zagreb, Vol.5 No.19, pp. 24-28

29. Pejanović, M., (2015), Država Bosna i Hercegovina i demokratija, University Press, Sarajevo

30. Pejanović, M., (2017), Bosna i Hercegovina i geopolitičke promjene u Evropi i svijetu na početku XXI stoljeća, Journal of economic and politics of Transition, Economic Institute of Tuzla, Tuzla, Year 19, No. 39, pp. 113

31. Pobrić, N., (2000), Ustavno pravo, Slovo, Mostar

32. Popis stanovništva u Bosni i Hercegovini (2013), in: Konačni rezultati Popis

2013, Nacionalnost 2013, 
http://www.statistika.ba/?show=12\&id=49800\#tab2, $\quad$ (accessed $\quad 20$ September 2018)

33. Rudolf, D., (2011), Hrvatska i Hrvati u Bosni i Hercegovini, Croatian Academy of Sciences and Arts,Adrias svezak, Zagreb, No. 17, pp. 221-234

34. Šarčević, E., (1997), Ustav i politika (Kritika etničkih ustava i postrepubličkog ustavotvorstva u $\mathrm{BiH}$ ), Ljubljana / Sarajevo

35. Tomaš, R., (2013), Causes of slow and inefficient transition of economy of Bosnia and Herzegovina and possibilities for its improvements, Poslovna izvrsnost, University of Zagreb, Faculty of Economics and Business, Zagreb, Year 7, No. 1, pp. 99-119

36. Topčagić, O., (2016), Status kandidata za članstvo u EU - Između izazova i slabosti, Politička analiza, CPU Printing Company, Sarajevo, Analiza No. 1/16, pp. 2-19

37. Ured zastupnika Republike Hrvatske pred Europskom sudom za ljudska prava (2016), in: Pregled prakse Europskog suda za ljudska prava (2016), Informacije o novim presudama i odlukama Europskog suda za ljudska prava, pp.

55,https:/uredzastupnika.gov.hr/UserDocsImages/dokumenti/PREGLED\% 20PRAKSE/PREGLED\%202 16.pdf, (accessed 14 October 2018)

38. World Economic Forum (2017): in: The Global Competitiveness Report 2017-2018, pp. 1-379, http://www3.weforum.org/docs/GCR20172018/05FullReport/TheGlobalCompetitivenessReport2017\%E2\%80\%9320 18.pdf (accessed 24 October 2018)

39. World Economic Forum (2018): in: The Global Competitiveness Report 2018 , pp. $1-657$, http://www3.weforum.org/docs/GCR2018/05FullReport/TheGlobalCompe titivenessReport2018.pdf (accessed 25 October 2018) 